„Kwartalnik Filmowy” nr 115 (2021)

ISSN: 0452-9502 (Print) ISSN: 2719-2725 (Online)

https://doi.org/10.36744/kf.850

(c) Creative Commons BY-NC-ND 4.0

Barbara Kita

Uniwersytet Śląski

https://orcid.org/00oo-0003-3616-9863

\title{
W parku sekwoi. Hitchcock/Marker/Godard
}

\author{
Słowa kluczowe: \\ Alfred Hitchcock; \\ Chris Marker; \\ Jean-Luc Godard; \\ pamięć; \\ obraz
}

\begin{abstract}
Abstrakt
Tekst stanowi refleksję na temat wzajemnych relacji Hitchcocka, Markera i Godarda. Główną ideą artykułu jest dostrzeżenie istotnego wpływu tego pierwszego na obu francuskich artystów, który w proponowanym ujęciu przejawia się w oddziaływaniu Zawrotu głowy (1958) na Pomost (1962), Bez stońca (1983) oraz Immemory (1997) Markera, a także na Nowa fale (1990) i Historie kina (1988-1998) Godarda. Autorka zauważa, że francuscy reżyserzy wykorzystali ten sam film Hitchcocka, ale w nieco odmienny sposób. Obaj zaakcentowali uniwersalność opowieści o pamięci/zapominaniu oraz docenili kunszt twórcy thrillera, który był doskonałym, czułym na obraz stylistą. Jednak każdy z nich na swój sposób kreował postać Hitchcocka w swych dziełach. Marker podkreślał umiejętność manipulowania czasem i przestrzenią, doskonałość niemal ascetycznej formy zawartej w Hitchcockowskich prostych obrazach. Godard polegał zaś na Hitchcocku jako na mistrzu kina, następcy wielkich malarzy, który wywierał na publiczność ogromny wpływ dzięki umiejętności opowiadania filmowych historii obrazami.
\end{abstract}




\section{Trzy indywidualności}

Stwierdzenie, że Alfred Hitchcock od wielu lat stanowi źródło inspiracji dla kolejnych pokoleń twórców na całym świecie, nie jest niczym odkrywczym. Reminiscencje obrazowe, cytaty gatunkowe, remaki, wykorzystywanie elementów poetyki/formy nie tylko w obrębie kina, ale także w reklamie, wideoklipach czy serialach to niemal powszechne praktyki nawiązywania do mistrza suspensu. Jednakże w tym, że dwaj twórcy, którzy bardzo silnie wpłynęli na sztukę drugiej połowy XX w. ${ }^{1}$, podejmują w swych jakże zróżnicowanych dziełach dyskusje z nim, jest coś zastanawiającego. Co łączy Chrisa Markera i Jeana-Luca Godarda z Hitchcockiem? I co łączy ich ze sobą w kontekście jego twórczości? Mam nadzieję, że odpowiedzi na te pozornie proste pytania sprowokują czytelnika do przemyślenia istoty twórczości obu francuskich artystów właśnie ze względu na ich dialog z Hitchcockiem. Być może ich fascynacja nim, podejmowanymi przez niego tematami oraz rozwiązaniami formalnymi, w tym pomysłowością narracyjną czy też widowiskowościa, zaczęła się od słynnych spotkań młodych twórców w siedzibie „Cahiers du cinéma". Wiadomo, że to właśnie reżyser Psychozy (Psycho, 1960) był jednym z niewielu filmowców, których krytycy francuscy pokochali bez zastrzeżeń (za efekt tej akceptacji można uznać wywiad rzekę przeprowadzony przez Truffauta). Marker nie był wprawdzie szczególnie blisko związany z jądrem ruchu, które tworzyli François Truffaut, Eric Rohmer, Jacques Rivette, André Bazin i JeanLuc Godard, i sytuował się raczej na jego orbicie ${ }^{2}$, lecz bez wątpienia znał dzieła twórcy bodaj najczęściej omawianego wówczas przez swoich kolegów. Po założeniu „Cahiers du cinéma” Bazin zresztą zaproponował Markerowi współpracę, ale ten odmówił, ponieważ był zaangażowany w inne sprawy - dużo pisał do „Esprit", przede wszystkim o literaturze. To właśnie Bazinowi Marker zawdzięcza określenie "filmowiec-eseista”, które pada po raz pierwszy po realizacji Listu z Syberii (Lettre de Sibérie, 1957) - tego „eseju dokumentowanego przez kino”3.

Co innego Godard, który od początku był jednym z najważniejszych jeunes Turcs (młodych Turków) skupionych w redakcji pisma wokół Bazina. Reżyser Do utraty tchu (À bout de souffle, 1960) odznaczał się aktywnością kinofilska, a swymi ocenami filmów chętnie dzielił się na łamach różnych czasopism filmowych. Pisał niemal o wszystkich produkcjach, które obejrzał. Szczególną uwagę poświęcał zaś kinu hollywoodzkiemu i Hitchcockowi, którego cenił od początku, tzn. od kiedy ten zaczął swą przygodę z filmem niemym.

Relacje dwóch awangardzistów francuskich nie były serdeczne. Współpracowali zaledwie raz, okazjonalnie, kiedy połączyła ich praca kolektywna przy filmie Daleko od Wietnamu (Loin du Vietnam, 1967). Godard za namową Markera, któremu spodobał się Żotnierzyk (Le petit soldat, 1963) zrealizował wówczas piętnastominutowy skecz Kamera-oko, zaś sam Marker został kimś w rodzaju koordynatora całości z ramienia grupy SLON - Société de Lancement des Oeuvres Nouvelles (Towarzystwo Upowszechniania Nowych Dzieł). Współpraca reżyserów była krótka, a po jej zakończeniu każdy poszedł swoją drogą. Marker kontynuował prace w ramach SLON i ISKRA aż do 1974 r., natomiast Godard założył własną grupę Dziga Vertov. To nie miejsce na roztrząsanie ich wzajemnych animozji. Można jedynie dodać, że mimo iż potrafili docenić wzajemnie swe filmy, 
byli zbyt dużymi indywidualistami, by ze sobą pracować. Paradoksalnie, przeszkodą było chyba to, że w gruncie rzeczy szli w podobnych kierunkach, zajmowały ich podobne kwestie. Obydwaj byli wielbicielami cytatów i estetyki kolażu (brikolażu), obydwaj doceniali znaczenie montażu, nadając mu szczególną rolę narzędzia intelektualnego, obydwaj także byli dość radykalni w wyborze tematów i sposobie ich prezentacji. Każdy z nich z nostalgii za kinem klasycznym (zarówno hollywoodzkim, jak i radzieckim) stworzył podstawy rozważań o historii i własnych obsesjach ${ }^{4}$. Godard w późnych latach 70 . wybrał wewnętrzne wygnanie w Szwajcarii, arystokratyczną izolację blisko swych korzeni, po lewej stronie Jeziora Lemańskiego; Marker osiadł zaś w Paryżu, wybrawszy anonimowość wśród milionów ludzi. W ten sposób ich drogi rozeszły się definitywnie.

Twórczość autora Psychozy stanowiła dla obu artystów punkt odniesienia, nie tyle będąc źródłem cytatów, ile prowokując do filmowej dyskusji. Obaj darzyli szczególną estymą malarski thriller Zawrót głowy (Vertigo, 1958), którego akcja została osadzona w San Francisco. O ile Marker nie zwlekał z bezpośrednim odniesieniem do tego filmu i już cztery lata po jego premierze subtelnie kreślił znaki parafrazy w swym 29-minutowym modelowym, najbardziej awangardowym i wpływowym dziele, czyli foto powieści Pomost (La jetée, 1962), o tyle Godard zareagował zdecydowanie później, bo dopiero w latach 1988-1998, w części 4A traktatu audiowizualnego Historie kina zatytułowanej Kontrola nad światem (Le contrôle de l'univers $)^{5}$. Zarówno jeden, jak i drugi potrafił wyrażać wprost poglądy na temat filmu, mediów technicznych i ich roli w świecie, a swe zróżnicowane technicznie, estetycznie i rodzajowo dzieła obaj traktowali jako wypowiedzi o charakterze teoretycznym. Dość łatwo można wyekstrahować z ich twórczości tę refleksję teoretyczną (często ją nawet podzielali). W związku z tym można zadać pytanie, czy również w poczynaniach Hitchcocka da się dostrzec pewien nadmiar o charakterze teoretycznym. Odpowiedź pomoże zrozumieć rodzaj przywiązania obu twórców francuskich do jego filmów - przywiązania polegającego na odnoszeniu się w dość otwartych formułach zarówno do pomysłów Brytyjczyka, jak i podejmowanych przez niego refleksji.

\section{Hitchcock w formie}

Jacques Aumont w pracy Teorie filmowców poświęca aż dwa stosunkowo duże rozdziały reżyserowi Okna na podwórze. Są to: Hitchcock: "suspens" jako wielka forma i Uczestnictwo emocjonalne: Hitchcock $i$ suspens. Żaden nie oddaje w pełni niuansów, jakimi operował reżyser, choć Aumont skupia się akurat na aspektach kluczowych dla Godarda i Markera. Na kilku stronach, na których walory filmów Brytyjczyka nie mogą zostać wyczerpane (ale też nie chodziło tu o stworzenie przekrojowej monografii w pigułce), Aumont śledzi potencjał teoretyczny działań Hitchcocka. Podkreśla przede wszystkim dwie kwestie: przywiązanie do znaczenia strony wizualnej filmu i służebność środków wobec zaangażowania widza w przebieg akcji. To właśnie jemu miały służyć wszystkie praktyki reżysera, na czele z suspensem jako idealnym narzędziem kontroli emocji widza. Hitchcock nie jest teoretykiem "sensu

stricto"; jego teoria - pragmatyczna-pozostaje w intymnej relacji z praktyka filmowa, która potrafi ułożyć na wzór kolejnych lekcji (...). Poza tym być może kino jest dla niego sztuka (na ten temat nigdy nie wypowiedział się wprost), jednak przede wszystkim jest spektaklem ${ }^{6}$. 
Twórca Psychozy był artysta wizualnym ${ }^{7}$, co na pewno zwiększyło u obu - wrażliwych na obraz - Francuzów przywiązanie do jego dzieł. Aumont podkreśla, że Hitchcock nie znosił amatorszczyzny, chciał panować w całości nad każdym filmem i każdym jego detalem, co także stanowi analogię do stylu pracy reżyserów francuskich. Warto podkreślić, że mistrz Markera i Godarda - wielbicieli montażu - przywiązywał olbrzymią wagę do możliwości tego środka wyrazu. To, co czyni z niego teoretyka filmu (a co można było wyczytać na przykład z rozmowy z Truffautem), to szczególna kontrola nad montażem (istotny jest tu kontekst hollywoodzkiego systemu produkcji), obejmująca szeroko rozumiane kadrowanie oraz długość ujęć. "Suspens" może zostać uznany za efekt uprawianej przez niego sztuki gry z czasem jako materia formalna filmu, a w konsekwencji odpowiedniego traktowania przestrzeni filmowej $i$ ciat aktorów ${ }^{8}$. Jest to idea bliska mise en scéne oraz pojęcia kamera-pióro9 ${ }^{9}$ W tym sensie suspens jest na swój sposób podpisem, swoistym autorskim écriture, ma charakter formalny oraz znaczenie w procesie konstrukcji całego filmu. Nie należy mylić suspensu z niespodzianka. Moje filmy nie sa kawatkami życia, to kawałki tortu - to dobrze znane aforyzmy autora Nieznajomych z pociagu (Strangers on a Train, 1951). Już tu czytelny staje się zamiar wysublimowanego wplecenia widza w film. Suspens pełnił $\mathrm{w}$ tym procesie istotną funkcję jako mechanizm przywiązania odbiorcy do obrazu, uwikłania go w złożony mechanizm kina. Hitchcock odczuwał potrzebę dyrygowania widzem, stąd jego doskonała znajomość maszyny-kina i kina jako maszynerii spektaklu i wyobraźni ${ }^{10}$; nie ma (de facto) suspensu, jest za to coś w rodzaju intelektualnej zagadki. Kryminat („whodunit”) wywotuje ciekawość oderwana od emocji ${ }^{11}$. Widz identyfikuje się w ten sposób z bohaterem i sytuacja, a zwłaszcza z bohaterem w niebezpieczeństwie (nawet jeśli jest on negatywny). Suspens powoduje wówczas nie tylko skupienie uwagi widzów, lecz także jej poszerzenie, wydłużenie w czasie, tak by ich reakcja stała się częścią spektaklu filmowego, jak określił to Truffaut we wspomnianej rozmowie. W interpretacjach twórczości reżysera najczęściej wskazuje się właśnie tę praktykę artystyczną, co jest wobec niego dość krzywdzące, gdyż w ten sposób niewidoczne stają się stosowane przez Hitchcocka wyrafinowane chwyty formalne - wizualne i fabularne.

Co ciekawe, ani Godard, ani Marker nie przywiązywali zbyt dużej wagi do Hitchcockowskiego suspensu. Dla obu liczyły się nie tylko poszczególne filmy jako takie, ale też cała twórczość reżysera jako sposób na zademonstrowanie pewnej postawy (ten aspekt interesował szczególnie Godarda) oraz uniwersalna tematyka ukryta pod zgrabnie skonstruowaną sensacją (co z kolei było ważne dla Markera). Wszystkich trzech łączy zainteresowanie kwestią pamięci, budowanie narracji opierające się na przestrzeni i czasie, złożone historie postaci, dbałość o szczegóły wizualne i inne elementy formalne. Najważniejszym dla Francuzów filmem był Zawrót głowy, do którego konsekwentnie (a nawet niemal obsesyjnie) powracali. Na potencjał budowania suspensu za pomocą - jakże istotnych - zabiegów wizualnych w filmach Hitchcocka zwróciła uwagę Ilona Copik, trafnie dostrzegając ich znaczenie w modulowaniu historii. Analiza twórczości autora pod katem sposobu wykorzystania przez niego na ekranie miejsc i krajobrazów prowadzi bowiem, jak się wydaje, do wniosku, że w filmach Hitchcockowskich tryby narracji maja swoje nierozerwalne powiazania ze strukturami przestrzennymi ${ }^{12}$ - pisze autorka, zwracając uwagę na motywy ikonograficzne z repertuaru symboli reżysera. Choć zwykło się sądzić, że Hitchcock osadzał akcję filmów przede wszystkim w miastach oraz budynkach, 
to jednak pojawiają się u niego przestrzenie o innym charakterze, które - choć krótko widoczne na ekranie - mają zasadnicze znaczenie dla zrozumienia jego twórczości. Taką przestrzenią jest stanowy park sekwoi. Obecność w nim bohaterów Zawrotu głowy sprawia, że film przeradza się na kilka minut z thrillera w traktat filozoficzny, co zauważa Copik, odwołując się do książki Petera Ackroyda: Obraz ten jest rozprawa o nostalgii, ale także obsesji, tworząc atmosferę nieustannych powrotów, w które wciagnięci są wszyscy uczestnicy ${ }^{13}$. Chodzi tu o słynną scenę, w której para bohaterów - bliskich sobie, lecz niemogących spełnić swego uczucia ze względu na szaleństwo kobiety oraz skomplikowane relacje - wybiera się na wycieczkę za miasto i staje przed pomnikiem przyrody w postaci przeciętego pnia sekwoi, na której słojach są zapisane wydarzenia historyczne. Można odnieść wrażenie, że w scenie tej czas zatrzymuje się na chwilę i pojawia się szansa na rozwikłanie zagadki głównej bohaterki. To tak, jakby para skonfrontowała się z historią świata, jakby jej istnienie stanowiło jakiś moment, który został zawarty między dwoma słojami wewnątrz pnia. Fabułę odtwarza szczegółowo Krzysztof Loska, wpisując film w kontekst tematów obecnych w całej twórczości reżysera, choć tym razem podlegających swego rodzaju demontażowi ${ }^{14}$. Loska proponuje wiele możliwych interpretacji filmu, wskazując również rolę spojrzenia i punktu widzenia w konstruowaniu narracji. Filmoznawca pisze: Scena w Pałacu Legii Honorowej pozwala nam również zrozumieć specyficzna funkcje spojrzenia, które wprawia w ruch maszynerię powtórzeń, odbić, zależności i imitacji ${ }^{15}$. Według Loski - co pokazuje także sam twórca w formie różnych znaków: spirali graficznych, kobiecego koczka w kształcie ślimaka, obrazu klatki schodowej widzianej z góry, słojów sekwoi - elementy wizualne podkreślają spiralność narracji filmu. Kształtowanie czasu i umiejętność odwzorowania jego skomplikowanej natury w złożonej przestrzeni filmowej, stworzone przez Hitchcocka serie powtórzeń, odbić, obrazów lustrzanych, zapętlenia czasu i przestrzeni czy wreszcie podwojenie (a nawet potrojenie, wziąwszy pod uwagę obraz kobiety w muzeum, które cyklicznie odwiedza Madeleine) postaci bohaterki, świadczą o tym, że wszystko opiera się tu na manipulacji czasem. Przy tym najistotniejszy jest współgrający z tymi elementami główny temat filmu: przezwyciężenie akrofobii przez detektywa oraz, co ważniejsze w tym kontekście, przypomnienie sobie przez bohaterkę własnej historii czy wreszcie zrozumienie, że prawda jest niemożliwa do odkrycia, ponieważ niemożliwe jest przypomnienie.

\section{Marker - Hitchcock}

Ze względu na poruszane przez Hitchcocka kwestie dotyczące pamięci, zapominania i przypominania, sięgania do historii oraz prób jej ocalenia Marker odnosił się do Zawrotu głowy już w Pomoście. To bodaj najsłynniejsze dzieło francuskiego twórcy obrosło w niezliczone komentarze, nie pora jednak, by w tym miejscu je przywoływać. W analizach 29-minutowego majstersztyku montażowego fotografii zwykle podkreśla się jego awangardowy charakter oraz wpływ na innych twórców i inne dzieła sztuki. W filmie kondensują się rozmaite elementy: opowieść o miłości; powrót do dzieciństwa i utraconej fascynacji niepowtarzalnym obrazem; przedstawienie wojny, skutków konfliktu nuklearnego oraz obozów koncentracyjnych; hołd złożony kinu (Hitchcockowi i Langlois) oraz fotografii; kwestia pamięci, przywiązania do tradycji muzealnych i do zwierząt. Wspomniany fragment 
Zawrotu głowy rozgrywający się wśród sekwoi zostaje w Pomoście przywołany niemal wprost w scenie, gdy para bohaterów udaje się do parku, by mężczyzna mógł sobie przypomnieć, co wydarzyło się wcześniej. To prawie kalka stworzona z fotografii, które ontologicznie zaświadczają o byciu, zapisaniu w historii, potwierdzeniu istnienia w czasie przeszłym. Fotografie mają dla Markera walor dokumentu, co podkreśla w swych refleksjach Raymond Bellour, pisząc w odniesieniu do Pomostu: Chciałbym zwłaszcza powiedzieć, dlaczego ten film fabularny (a nawet "science fiction") może wydawać się niezbędny przy wyborze kanonu dokumentu (...). To proste i dziwne zarazem (...), to kwestia fotografii, która ma nieunikniony dokumentalny wymiar ${ }^{16}$. Fotografia zamraża chwilę, pokazuje prawdziwość uchwyconego momentu i dlatego staje się dla Markera - nie tylko w Pomoście - podstawowym materiałem twórczym. Ze względu na zasadniczy temat filmu - pamięć - reżyser wykorzystał fotografie tak, by stworzyć pozór ruchu filmowego, zamiast zrealizować tradycyjny film, gdyż to właśnie zdjęcie ma szczególną właściwość dokumentu pamięci. Zależało mu na wyeksponowaniu kwestii prawdy i pamięci, które są wpisane w fotografię, a które stały się także tematem Zawrotu głowy. Celem powtórnej lektury amerykańskiego filmu we francuskiej, awangardowej wersji, zaskakująco odpowiedniej do podjęcia problematyki pamięci, podróży w czasie, przestrzeni i historii, było poszukiwanie przez bohaterów momentów w (nie)pamięci, które mogą przywrócić wspomnienia, tak by stały się realne.

Marker najwidoczniej stwierdził, że film Hitchcocka jest doskonałym sposobem na wypowiedzenie własnych obsesji. Spirala czasu łączy się ze spiralą przestrzeni, jedno nie istnieje bez drugiego, co dodatkowo uzasadnia zastosowanie uruchomionych montażem fotografii, które utrzymuja swa paradoksalna prawdę: zarazem nieruchome (w przestrzeni) i ruchome ( $w$ czasie $)^{17}$. Zmontowane w odpowiedni sposób zdjęcia Markerowskiego filmu (nazywanego przez samego autora photo-roman lub ciné-roman, co miało oddawać fotograficzny lub kinowy charakter opowieści ${ }^{18}$ ) wyrażają powtórzenie gestów kobiety i mężczyzny pragnących odkryć tajemnicę. W tym celu para udaje się do parku, zbliża do otoczonego ogrodzeniem eksponatu przywiezionego z innego miejsca i odgrywa te same gesty, jakie wykonali pierwotnie Madeleine i Scottie. W tym krótkim momencie, złożonym z kilku obrazów, widzimy, że Pomost jest podobny do Zawrotu głowy: bohaterka pierwszego filmu, podobnie jak Madeleine, podpina włosy, zaś para u Markera wskazuje z pewnej odległości miejsca w przekroju pnia zaznaczone słojami i plamami. W filmie pojawia się także zbliżenie wskazujących dłoni - jest to gest identyczny z tym ukazanym w oryginale. Marker sądził, że dzieło Hitchcocka pokazuje, na czym polega praca pamięci, jak skomplikowany jest proces anamnezy, zapominania i przypominania, przywoływania wspomnień za pomocą miejsca, okoliczności, detali, obrazów. Obydwaj twórcy byli owładnięci pasją zgłębienia mechanizmu pamięci, a ich bohaterowie dążyli do odkrycia przeszłości, mieszając ją z teraźniejszością. Dla Markera idealnym materiałem były fotografie, nieruchome pamiątki z minionych chwil, które - wprawione w ruch montażem - zaczynają mówić o przeszłości i przyszłości. Pamięć, zapominanie i obsesyjne, a zarazem nieskuteczne poszukiwanie własnej historii i przyszłości to elementy łączące w istotny sposób twórczość Markera i Hitchcocka.

To historia człowieka naznaczonego obrazem z dzieciństwa - brzmi zdanie rozpoczynające foto powieść. Markera prześladował pewien obraz, którym był kadr 
z filmu Wspaniate życie Joanny d'Arc (La merveilleuse vie de Jeanne d'Arc, reż. Marco de Gastyne, 1928) przedstawiający zbliżenie twarzy aktorki Simone Genevois. To ten obraz nauczył siedmioletniego chłopca, w jaki sposób twarz - najprecyzyjniej na świecie - może wypetnić ekran. (...) To jest coś, co powraca nieustannie, co miesza się ciagle z każda chwila życia. (...) Można to określić jednym słowem - miłość. Zrozumiałem to dopiero po odkryciu kina, kiedy urosłem, kino i kobieta stały się dwoma pojęciami absolutnie nierozerwalnymi ${ }^{19}$. To dziecięce doświadczenie wyjaśnia częstotliwość ujęć twarzy kobiet w dziełach Markera, tłumaczy intensywność zbliżeń twarzy bohaterki Pomostu, kiedy śpi, myśli, wspomina, przygląda się martwym zwierzętom w muzeum, do którego wybrała się z mężczyzną owładniętym obsesją na punkcie jej obrazu (zbliżenia twarzy). Tyle zostaje zawarte w historii, którą rekonstruujemy, skądinąd przeczuwając, że bohater nie wychodzi z podziemnego więzienia, lecz poddawany eksperymentom, śni, podróżuje jedynie w wyobraźni, z czym koresponduje fotograficzny zapis opowieści ${ }^{20}$. Zawrót głowy ujął Markera prawdopodobnie także ze względu na ciekawy sposób ukazania kobiet, które skutecznie omamiają Scottiego: Madeleine/Judy, Carlotty z portretu oraz Midge, koleżanki z pracy. Dość łatwo można zauważyć podobieństwa między bohaterką francuskiego filmu a trzema Hitchcockowskimi postaciami. Markerowi udaje się oddać te analogie przez niejako malarskie uchwycenie, podkreślenie charakterystycznego koka w niektórych scenach czy też przez pokazanie kobiet w półzbliżeniu lub zbliżeniu, niemal analogiczne do ujęć z filmu Hitchcocka. Ta obsesja obrazu, twarzy kobiety, której nie sposób zapomnieć, dzięki której chce się odzyskać pamięć, a ją samą zmusić, by odzyskała pamięć, to kolejne elementy zapożyczone przez Markera od reżysera Zawrotu głowy. Mimo sceptycyzmu Loski ${ }^{21}$ skłaniam się do takiej interpretacji postaci Madeleine, w której jej imię odsyła do Proustowskiej magdalenki, babeczki uwalniającej wspomnienie będące w obu filmach zasadą budowy znaczenia. Magdalenka swym smakiem i zapachem przywraca pamięć, dzięki czemu przeszłość staje się teraźniejszością. W filmach taką moc mają obrazy: wizerunki kobiet w przypadku bohaterów, dama z naszyjnikiem z portretu malarskiego - w przypadku Madeleine. Markerowskiemu bohaterowi z przyszłości pamiątka-obraz umożliwia zaś wejście w przeszłość dzięki twarzy zapamiętanej kobiety.

Pamięć nie jest prostym mechanizmem, zatem pokazanie jej działania w filmie nie może być zwykłym zapisem obrazów odsyłających do jej śladów. Bohaterowie Pomostu spędzają dużo czasu w muzeum, w którym z zasady kumulują się różne epoki i obiekty, a odwiedzający zostają przeniesieni w dalekie miejsca. Postaci przemierzają sale muzealne wypełnione martwymi, wypchanymi zwierzętami będącymi formą zatrzymania historii. Muzeum i pomost: dwie przestrzenie czasu, a zwłaszcza dwa typy spojrzenia, miejsca wrzucone w pamięć22. Odniesienie awangardzisty do klasyki kina również staje się niejako podróżą w czasie, kiedy kieruje on uwagę na film z lat 50. już nie po to, by nawiązać do znanej fabuły, lecz by dowartościować formułę kina hollywoodzkiego, które w latach 60. w Europie wydawało się mocno przestarzałe, zaś w Ameryce - wyeksploatowane. Mężczyzna podróżujący między różnymi okresami, unieruchomiony w podziemiach, jest jak widz (i sam Marker), który porusza się w czasoprzestrzeni dzięki historiom opowiadanym przez kino. A więc podróż w czasie między soba i soba, która jak wszystkie podróże w czasie może być tylko podróża dzięki obrazom i przez myśl, podróżowaniem w myśleniu obrazem. To wtaśnie nazywa się Pamięcia. U Markera funkcjonuje 
ona dokładnie jako matryca narracyjna i dyskursywna, tylez diegetyczna (jest tematem), co formalna (ucieleśniabyt między wizualnościa kina i fotografii) ${ }^{23}$. Znaki nawiązujące do kwestii temporalnych wypchane zwierzęta w muzeum, wyśniona/wyobrażona podróż w czasie, sekwencja w parku przy przeciętym pniu sekwoi (słowa kobiet: moje życie zawiera się $w$ tej malutkiej przestrzeni u Hitchcocka oraz pochodzę stamtad u Markera) - obrazują spiralność czasu, dialektyczny charakter trwania percepcji i fenomenu.

Bez słońca (Sans soleil, 1982) można postrzegać jako metafilm wobec Pomostu $u^{24}$. Marker proponuje w nim transkulturową podróż przez niemal cały świat - od postindustrialnej Japonii przez preindustrialną Afrykę do kilku innych miejsc. Punktem odniesienia dla filmu był jednak nie tylko Pomost, ale także - ponownie - Zawrót głowy, którego topografię reżyser dokładnie rekonstruuje. Pominę szczegółowe i obszerne interpretacje tego filmu i skupię się na Hitchcockowskich kadrach opisywanych powyżej. Jarmo Valkola wskazuje znaną z poprzednich filmów Markera estetyczną praktykę, która łączy obrazy architektoniczne, malarskie i zdjęcia: Film wyjaśnia szczególne uczucie przemieszczania w czasie połaczone ze światem obrazów. Nieruchomość fotograficzna i ruch kinowy prowadza do produkcji poglądowego opisu inscenizowanych wydarzeńn ${ }^{25}$. Podróżując między Japonią a Afryka, Marker dość nieoczekiwanie dla widza - postanawia wstąpić do San Francisco, by pojeździć stromymi ulicami i w ten sposób nawiązać wprost do filmu Hitchcocka. Analizując geografię filmową mistrza suspensu, Copik zauważa: Miasto $w$ filmie odtworzone jest z typowa Hitchcockowska precyzja, wiernie oddaje klimat i topografie realnego San Francisco ${ }^{26}$. Autorka pisze ponadto, że jego rola w filmie jest równie ważna jak rola postaci. Reżyser nie bez powodu wybrał San Francisco, które faktycznie przyprawia o zawrót głowy, kiedy jeździ się krętymi i spadzistymi uliczkami, tak jak robi to wynajęty detektyw, śledząc Madeleine, a co krok po kroku powtarza Marker, poszukując śladów filmowych miejsc - starszych o dwie dekady w latach 80. - niejako sprawdzając Hitchcocka jako ich dokumentalistę.

Początkowe sekwencje Bez słońca zawierają analogie do Pomostu, reżyser pokazuje bowiem pasażerów śpiących na ławkach promu kursującego pomiędzy japońskimi wyspami, czemu towarzyszy narracja z offu o naturze świata, percepcji i wyobraźni. Dopiero w dwóch ostatnich dziesięcioleciach XX w. za sprawą Bez słońca, Level 5 i Immemory Marker podjął ponownie zapoczątkowaną w latach 60. refleksję o pamięci i czasie. W tym pierwszym obrazy z filmu Hitchcocka powracają jednak nieco inaczej niż w Pomoście; nie stanowią aluzji, ale raczej sprawdzian. Wycieczka Markera po San Francisco śladami plenerów filmowych powoduje, że obrazy się dubluja, to, co zostało pokazane wcześniej w thrillerze, ożywa po latach: została kwiaciarnia, gdzie bohaterka kupowała kwiaty na grób, zniknął natomiast mały wiktoriański hotel, w którym mieszkała Madeleine - zastąpiły go betonowe budowle; oprócz tego na użytek słynnych scen z kręconymi schodami i samobójstwem reżyser dobudował do hiszpańskiej misji fałszywą wieżę. Francuski twórca zatrzymał się nieco dłużej jedynie przy Golden Gate, pokazując z bliska miejsce pod mostem, gdzie Scottie wyłowił niedoszłą samobójczynię. Uratował ją. A może to ona uratowała jego? - pyta Marker w swym eseju filmowym. Pozostały jeszcze inne charakterystyczne lokacje: Chinatown, Russian Hill, The Fairmont czy Lombard Street, które reżyser odnosi zarówno do realnej geografii, jak i fikcji filmowej, podporządkowując się spirali przestrzeni i czasów, które mieszają się ze sobą jak 
obrazy - te z kina i te z rzeczywistości. Dwa światy komunikuja się. Pamięć jest dla jednego tym, czym dla drugiego historia: niemożliwościq - komentuje narrator słowami Markera. W rzeczywistości bowiem spirala ulic i miejsc wyznacza spiralę czasu - dodaje reżyser, mieszając obrazy z filmu Hitchcocka i własnego eseju dokumentalnego. Marker, wędrując po mieście ukazanym w filmie, który widział 19 razy (i to wyłącznie do 1982 r.!), dochodzi do wniosku, że Hitchcock niczego nie wymyślił, bo wszystko (poza wieżą) było już wcześniej. Zaświadczają o tym tysiącletnie sekwoje, które przedstawił także Francuz, proponując najpierw echo sceny z Zawrotu głowy, a następnie przeskakując do obrazu plastra z przekrojem drzewa w paryskim parku i nawiązując w ten sposób do własnego filmu - Pomostu. Palimpsest obrazowy? Nie w tym przypadku; raczej palimpsest czasu i przestrzeni, uruchomiony dzięki reminiscencji obrazów. Mamy tu do czynienia z kinową grą z pamięcia, jak pisze Paweł Mościcki, odwołując się do refleksji Alaina Bergali ${ }^{27}$. Jej przedmiotem jest to, co powraca w innej formie, po tym jak zostało zapomniane. Sposobem na to jest wyglad lub pojawienie sie, a rejestrem - melancholia ${ }^{28}$. Bergala wspomina o rejestrach pamięci w kinie Godarda, ale ich funkcje i znaczenie dla konstruowania filmów wydają się uniwersalne w praktyce artystycznej i z pewnością trafnie opisują doświadczenie Markera.

Pielgrzymka do San Francisco to nie jedynie przejażdżka w hołdzie dla mistrza suspensu (dwa lata po jego śmierci), to poddanie się działaniu przestrzeni i czasu, rodzaj nawiązania do pejzaży, które nadal istnieją w rzeczywistości i ciągle będą ożywać dzięki filmowi Hitchcocka. Jednak nie sama kwestia pamięci łączy oba filmy. Bez słońca, określany eksperymentalnym dokumentem etnograficznym, absolutnie postmodernistycznym $i$ „zdecentralizowanym" ${ }^{\prime 29}$, jest opowieścią o Innym, o strachu przed obcym, nieznanym. Czy pamięć jest dla Markera kategoria formalna, która ustanawia tożsamość euro-amerykańska jako nie-rasowa, nie-tożsama z mitycznym źródtem reprezentacji ${ }^{30}$ - zastanawia się Catherine Russell. Dostrzega ona związek filmu Markera z Zawrotem głowy w kilku aspektach. Obie historie (podobnie jak Pomost) opowiadają o człowieku, który zmaga się z własną tożsamościa, poszukując w przeszłości i we własnej pamięci wrażeń i obrazów niezbędnych do przypomnienia zdarzeń minionych. W Zawrocie głowy problemem był lęk wysokości, w filmie Markera jest nim strach przed Innym, obawa przed wejściem w relację z jego spojrzeniem. W jaki sposób podróżować, jak zbierać obrazy, które pozwoliłyby zdać sprawę z własnego doświadczenia odmienności kulturowej, bez reifikacji, bez obiektywizacji, bez przypisania miejsca, które istniałoby tylko w pamięci, bez „zmieniania go"? 31 - zastanawia się Russell po wnikliwej interpretacji Bez stońca.

Marker nie przestawał poszukiwać odpowiedzi na dręczące go pytania o naturę pamięci, mechanizmy zapominania i przypominania oraz wspominania. A że był postacią niezwykle otwartą na wszelkie nowinki techniczne, piętnaście lat po Bez słońca stworzył interaktywny CD-ROM Immemory (1997). Przyznał, że poczuł się jak dziecko w sklepie z zabawkami, mogąc bawić się tą technologia, a przy tym okazało się, że CD-ROM spełnia jego marzenia o samowystarczalności twórczej i jest wprost idealnym narzędziem do zobrazowania pracy pamięci. Tematyka pamięci niemożliwej sygnalizowana przez Hitchcocka i Markera powraca w formie interaktywnego dyspozytywu, maszyny (do) zapamiętywania. Tytuł odnosi się do niemożliwości pamięci jako takiej, zarówno tej osobistej, jak i tej dotyczącej wydarzeń światowych. Bellour sugeruje, że Marker rozpoczął refleksję nad 

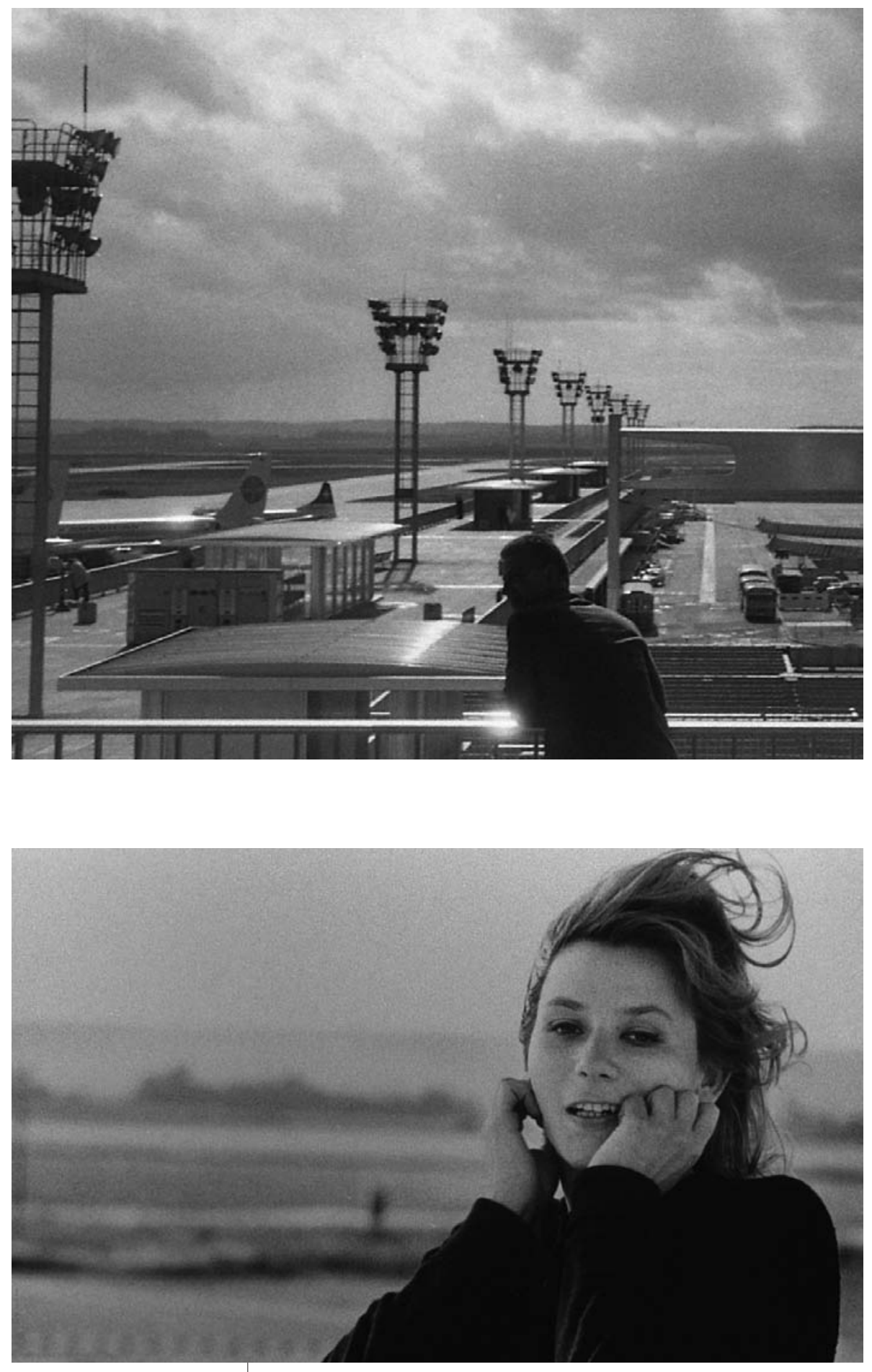

Pomost, reż. Chris Marker (1962) 
bliskimi mu kwestiami być może już wtedy, kiedy zacząt pisać i filmować, kiedy pamięć, począwszy od wojny i obozów [twórca był scenarzystą Nocy i mgły /1956/ Alaina Resnais], stata się je go problemem, jego niemal jedynym tematem ${ }^{32}$. Sądzę, że Immemory, oprócz tego, że jest znakomitym przedsięwzięciem technicznym, choć dziś już trudno dostępnym, w archaicznym formacie, stanowi idealne zwieńczenie niemal całej drogi twórczej artysty. Swą twórczość poświęcił on w znacznym stopniu odtworzeniu maszynerii pamięci, którą można uruchomić dzięki różnym, często mieszanym formom pisma, kina, wideo, złożonym technikom obrazowym i dźwiękowym. W dziele pojawia się szczególny styl wypowiedzi, którą Barbara Laborde określa następująco: Sztuka poetyki, ponieważ film u Markera to kombinatoryka, miejsce nieustannej wymiany fragmentów, różnych "écriture”, stużacej stworzeniu nowego dzieła, począwszy od wcześniejszych mniej lub bardziej znanych filmów, anonimowych obrazów, nieświadomego lub automatycznego cytowania ${ }^{33}$. Lev Manovich podkreśla, że dopiero z czasem CD-ROM-y zaczęto wykorzystywać świadomie. Badacz wskazuje przy tym Immemory Markera jako przykład celowego i krytycznego (w sensie estetyki) użycia tego medium. Teoretyk dostrzegł również istotność nowego medium, które wymusiło niejako ponowne zdefiniowanie języka kinowego. CD-ROM łączył filmowy iluzjonizm oraz graficzna estetykę kolażu z jego heterogenicznościa i nieciagłością ${ }^{34}$. Cechy te były odpowiedzią na potrzeby Markera, który od lat stosował różne praktyki kolażowe, mieszając elementy filmowe, wideo i fotograficzne, tworząc rozbudowane palimpsesty obrazowe i słowne.

Formuła interaktywnego CD-ROM-u umożliwiła Markerowi bezprecedensowe stworzenie architektury obrazów i dźwięków oraz sformalizowanie związków między różnorodnymi elementami. Użytkownik jego atlasu porusza się po nim, konstruując własne bifurkacje, wypróbowując nowe trasy na mapie zaproponowanej przez artystę, lecz ponieważ liczba konfiguracji dokonywanych przez gracza jest ograniczona, w końcu i tak trzeba zrekonstruować ścieżki samego Markera, który prowadzi nas po „terytoriach” takich jak: Podróż, Wojna, Fotografia, Kino, Poezja, Pamięć, Muzeum i XPlugs. Każda podróż zaczyna się od „wyspy” wyznaczającej obszar tematyczny, do którego zostaje odesłany gracz. Marker zbiera rozmaite - własne i cudze - teksty, dając każdemu czytelnikowi/zwiedzającemu/graczowi możliwość, by ten sam odkrył mechanizmy pamięci. Reżyser prowadzi go po własnych śladach, obsesjach, (fałszywych?) pamiątkach z dzieciństwa i licznych podróżach. Autor wskazuje trzy filmy, które uważa za kultowe. Jednym z nich jest Zawrót głowy. To film kluczowy dla całego przedsięwzięcia opartego na autobiograficznych wątkach i zanurzonego w pamięć, historię oraz wspomnienia. Marker o „filmie-węźle”, do którego prowadzą niemal wszystkie drogi atlasu, mówi: To jest magdalenka. Żaden film nie pokazał nigdy w ten sposób, że mechanizm pamięci, jeśli się go rozreguluje, może stużyć czemuś innemu niż wspomnienie: rozpoczęciu życia i w końcu przezwyciężeniu śmierci. Banałem jest powiedzieć, że pamięć kłamie $e^{35}$. Te słowa uzmysławiają dobitnie, na czym polega(ł) fenomen filmu Hitchcocka, jak bardzo przykleił się do wyobraźni Markera, który wiąże palimpsestowy obraz Prousta z mistrzem kina po to, by pokazać, w jaki sposób powieść pierwszego i film drugiego stanowią wzory funkcjonowania mechanizmu pamięci. Francuski reżyser stara się także zaprezentować maszynerię pamięci. W tym przypadku technologia pokonuje czas, wyciaga $\mathrm{z}$ albumów zabalsamowane fotografie, z kina stare kadry, z kufra na strychu pożółkłe karty pocztowe, 
wyblakłe fragmenty prasy, obrazy malarskie itp., przekształcając to wszystko w żywe, aktywne archiwum. U odbiorcy pojawia się nieuchronnie skojarzenie z Atlasem Gerharda Richtera oraz Atlasem obrazów Mnemosyne Aby'ego Warburga. Zagadnienie to nie jest przedmiotem moich rozważań, w tym kontekście można jednak podkreślić, że wszystkie powyższe atlasy pamięci są lokowane w przestrzeni i mają strukturę otwartą ${ }^{36}$.

Częściowo autobiograficzny, a częściowo fikcyjny testament pamięci Markera ${ }^{37}$ przedstawia go jako artystę i człowieka w najbardziej wyrazisty sposób ze wszystkich jego dzieł. Jednocześnie udowadnia, że wszystkie drogi, którymi podążał, prowadziły do problematyki pamięci. Kierowała nim przemożna chęć pokazania, na czym ta pamięć polega, a służyły temu strategie palimpsestowe, reminiscencje, anamnezy, nawiązania do swoich i cudzych wypowiedzi różnego typu, podporządkowane temu, by efekt pamięci/zapomnienia wywołać i zbliżyć się do jego istoty. Dlatego w tak uprzywilejowany sposób traktował Zawrót głowy, którego twórca prostymi środkami filmowymi przedstawiał interesującą go tematykę, docenił elegancję ubogich środków, choć dziś może trudno zrozumieć, jak wiele może sugerować widok Kim Novak wyciagajacej rękę w stronę przekroju sekwoi, lub uchwycić gest zatrzymany na dwóch kruchych fotogramach ${ }^{38}$. Po raz kolejny natura kina odegrała w twórczości Chrisa Markera szczególną rolę. Kinematograf to naprawdę maszyna do ponownego montowania czasu, jego naprawy i poszukiwania, jedyna do świadomego zanurzenia nas w jego zawrotna spirale. Ten filmowy zawrót przywołany pod trzema postaciami w dziełach Markera ("Pomoście”, "Bez słońca”, "Immemory”) symbolizuje to w najwyższym stopniu - "Zawrót głowy" 39 .

\section{Godard/Hitchcock}

Godard pojmował pamięć inaczej niż jego francuski kolega, w odmienny sposób także prezentował ją w swych filmach. Początek lat 80. otworzył u niego (podobnie jak u Markera) nowy etap twórczości, który można byłoby określić jako powrót do kina oraz zainteresowanie historią i pamięcią. Co ciekawe, zbiegło się to w czasie z datą śmierci Hitchcocka (1980 r.). W ujęciu Godarda pamięć miała charakter uniwersalny, wynikający z historii ludzkości oraz z rekonstruowania własnych, indywidualnych historii. Nie interesowało go jednak poznanie mechanizmu pamięci, co było przedmiotem poszukiwań Markera, lecz odkrywanie anamnezy jako formuły zapomnienia i przypominania. Powiedziałabym nawet, że historia i pamięć miały dla Godarda wydźwięk zdecydowanie tragiczny, co można dostrzec zwłaszcza w dziele stanowiącym punkt kulminacyjny jego zainteresowań tymi kwestiami, a mianowicie w Historiach kina. To tu doszło do połączenia obrazów według „dialektyki szoku", czego najdobitniejszym i najczęściej komentowanym przykładem jest zestawienie dokumentalnego zdjęcia, na którym widać ciała ofiar z Auschwitz, z ujęciem anielskiej twarzy Liz Taylor z hollywoodzkiego filmu Miejsce pod słońcem (A Place in the Sun, reż. George Stevens, 1951). Wielopoziomowy (mentalny) dyspozytyw złożony z setek materiałów wizualnych (dokumentów, fotografii, fikcji, malarstwa) oraz fragmentów powieści, pism filozoficznych, poezji jest - zgodnie z intencją autora - dziełem otwartym. Obrazy powtarzają się w różnych konfiguracjach i mieszają ze soba, tworząc, niekiedy w połączeniu ze słowami, złożone palimpsesty. Od lat 80 . Godard coraz wyraźniej akcentuje coś, co interesuje go najbardziej, a mianowicie 
refleksję na temat statusu historii, kina, obrazu i sztuki w XX w. I to właśnie sztuce poświęca szczególną uwagę. Na tym obszarze jedno z najważniejszych miejsc zajmuje według reżysera Nowej fali (Nouvelle vague, 1990) Hitchcock. Godard traktuje jego twórczość w sposób całościowy, niejednokrotnie podkreślając znaczenie Zawrotu głowy zarówno dla kina, jak i dla niego samego.

Widział on w Hitchcocku artystę nie tylko filmowego, lecz także takiego, który reprezentował sztukę w ujęciu historycznym jako spadkobierca Paula Valery'ego oraz Leonarda da Vinci: Wedtug mnie należy on do wielkich artystów tego wieku. Jego filmy nie zostały zrealizowane w sposób prosty, według przepisu, były trudne, zmysłowe, tajemnicze. Odnióst sukces, to niezwykle rzadkie. Bardzo niewielu artystów $w$ Historii spotkało coś podobnego. Może Rubensa ${ }^{40}$; to jedyny poeta wyklęty, który odnióst sukces $^{41}$. Francuz często podkreślał wyjątkowość filmów Hitchcocka, który był dla niego przede wszystkim artystą wizualnym (słowo „artysta” pojawia się w Historiach niejednokrotnie, pulsując na twarzy mistrza suspensu); uważał, że z czasem można zapomnieć fabułę i następstwo wydarzeń, jednak nie sposób zapomnieć obrazów. I tak jest w przypadku twórcy Nieznajomych z pociagu. Znaczenie i wartość obrazu polegają na tym, że nawet w formie jednostki wyizolowanej z filmu, niejako „zatrzymanej” po zastopowaniu ruchu taśmy filmowej, ma on nadal sens, jest istotny i może zostać zapamiętany, tak jak sceny czy pojedyncze kadry z Zawrotu głowy, które zostały wmontowane do Kontroli nad światem.

Godard pisał o filmach Hitchcocka, jeszcze zanim sam zaczął reżyserować. W Nieznajomych z pociagu dostrzegł supremację tematu nad obrazem oraz niemal tragiczny wymiar filmu, który jak żaden dotychczas potrafił zdać sprawę z kondycji człowieka wspótczesnego, mającego uciec przed upadkiem bez pomocy boga (...). Sztuka Hitchcocka może nam jedynie pokazać prometejski obraz swojej morderczej raczki, która lęka się nieznośnego blasku ognia ${ }^{42}$. W latach 50 . francuski reżyser napisał dla „Cahiers du cinéma" recenzje Człowieka, który wiedział za dużo (The Man Who Knew Too Much, 1956) oraz Niewłaściwego człowieka (The Wrong Man, 1956); nie zrecenzował natomiast Zawrotu głowy, choć w zestawieniu sporządzonym zgodnie z tradycją pisma umieścił go wśród najlepszych filmów z 1958 r., a później wracał do niego w kontekście motywu pamięci. W recenzji Niewłaściwego człowieka pisał: Bezpośrednie dane świadomości - Alfred Hitchcock po raz kolejny udowadnia, że kino, lepiej niż filozofia czy powieść, potrafi je pokazać (...). Poczawszy od "Okna na podwórze" reżyser świadomie mnoży efekty "naskórkowe” i jeśli odsuwa fabułę na dalszy plan, to po to, by ujawnić oczywiste piękno [obrazu $]^{43}$.

Po śmierci Hitchcocka Godard w rozmowie z Serge’em Julym z „Libération” podkreślił rolę, jaką stary mistrz odegrał w historii kina będacego dzieciństwem sztukit ${ }^{4}$. Według francuskiego reżysera medium, które zawiera w sobie wszystkie inne sztuki, jest - w swej popularnej wersji - demokratyczne, w przeciwieństwie do muzyki i malarstwa mających cechy dziedzin elitarnych. I to właśnie Brytyjczyk przyczynił się do popularyzacji sztuki. Hitchcock byt "widzacym", "przewidywat" swe filmy, nim zostały napisane ${ }^{45}$; to także jedyny twórca, który mógł przenieść na ekran dzieła Prousta. Nie musiał jednak tego robić, dokonując adaptacji konkretnej książki pisarza, ponieważ robił to niejako mimochodem. Francuski reżyser wskazał także związki Hitchcocka z mistrzami malarstwa, zauważając, że z Tintorettem łączy go bliska relacja z publicznościa, chęć wpłynięcia na nią i potrzeba, by uznała ona jego dzieła za wielkie, a z Cezanne'em szczególna zdolność do operowania 
przedmiotem - reżyser potrafił pokazać butelki wina Bordeaux tak, jak malarz przedstawiał jabłka. Także "Zawrót głowy” jest czystym malarstwem ${ }^{46}$ - twierdził Godard. Wszak kino w ogóle odnosi się do malarstwa (i z niego czerpie), a stylu reżysera Sznura nie sposób pod tym względem pomylić z innym: Jak $u$ wielkich malarzy, tak $i$ u niego pojawia się najpierw jeden obraz malarski, a potem dochodza inne ${ }^{47}$. Pod koniec długiej sekwencji poświęconej metodzie Hitchcocka z napisu „Artysta” pozostaje tylko część „Sztuka” (l'Art) - Godard zaprezentował twórcę Okna na podwórze jako wielkiego artystę kina, który stał się inkarnacją sztuki ${ }^{48}$.

Francuz twierdził ponadto, że w przypadku Hitchcocka nie opowiada się filmów, lecz to, co się w nich widziało - opisuje się obrazy ${ }^{49}$, a jako że sam przywiązywał szczególną wagę do ich mocy i wiarygodności, unikał ich niepotrzebnego pomnażania; starał się operować obrazami, które już istnieją. Z tego powodu materiały found footage przeważają w Historiach kina nad innymi sposobami obrazowania. Obraz wiąże się silnie ze sprawiedliwościa, ponieważ jest dowodem. Kino daje za każdym razem materialny dowód tego, co się wydarzyło ${ }^{50}$. Sama śmierć Hitchcocka wyznaczyła według Godarda moment przejścia z jednej epoki kina do drugiej, co oczywiście wiązało się również ze zmianami technicznymi, które nastąpiły na tym obszarze w latach 80.

W Historiach kina Godard wspomniał Hitchcocka 23 razy, zaś Kontrola nad światem (część 4A) jest już hołdem złożonym temu twórcy. Sekwencja rozpoczyna się kilkunastoma ujęciami rąk przedstawionych na płótnach malarskich i w rzeźbach. Na nie zostaje nałożony napis „Artysta” (l'Artiste), a zaraz potem z czerni wyłania się twarz Hitchcocka. W części tej Godard wyłożył to, o czym pisał przez wiele lat, czyli problem kina i jego powinności wobec sztuki i historii oraz kwestię roli Hitchcocka w procesie samego podnoszenia kina do rangi sztuki (do tego odniosłam się w poprzedniej części tekstu). Zapominamy opowiadane historie, a nawet scenariusz, ale nie przedmioty, które sa pokazane w taki sposób, że szczegót (jak kok z włosów Madeleine, klucz wpychany do kratki, zbliżenie twarzy) nie tylko zostaje zapamiętany, ale - ze względu na emanująca z niego moc - usuwa cała resztę w niepamięćc ${ }^{51}$. To właśnie na tym, w interpretacji Godarda, polega działanie obrazów/pamięci w kinie Hitchcocka. Francuz traktował go w taki sposób, jak czynił to Proust w odniesieniu do narratora w Poszukiwaniu straconego czasu, którego pamięć zostaje uruchomiona dzięki magdalence. Podobnie dzieje się w filmach: To dzięki przywołanym uczuciom czas zostaje nagle odnaleziony, co sprawia, że świat przeszły staje przed nami. Ta reminiscencja wyptywa z empirycznego zrozumienia świata ${ }^{52}$. Dlatego Proustowska magdalenka funkcjonuje jak wspomnienie. Podobne działanie mają detale $\mathrm{w}$ filmach Hitchcocka.

Hitchcock był twarzą Kontroli nad światem. Godard dowodzi tu, że jako reżyser hollywoodzki potrafił on nie tylko umiejętnie zapanować nad widzami, oddziaływać na nich, ale także zadowolić rzesze krytyków na całym świecie. W gruncie rzeczy nie można go porównać z żadnym twórcą działającym w tym samym czasie. Nikt nie miał tak dużego wpływu na ludzkie reakcje i emocje, posługując się jako narzędziem kinem popularnym, a zatem sztuką masową. Wyjątkiem może być Chaplin - inna ikona kina, twórca umiejący zjednać sobie widzów wdziękiem i kruchością ${ }^{53}$. Alfred Hitchcock zdołał dokonać tego, co nie udało się Aleksandrowi, Juliuszowi Cezarowi, Napoleonowi i Hitlerowi, czyli zawładnać całym światem - w ten sposób Godard usprawiedliwia uprzywilejowaną pozycję artysty w His- 
toriach kina. Myśl tę reżyser kontynuuje już po skończeniu prac nad tym multimedialnym dziełem z lat 90., pisząc: Hitchcock jako jedyny zdołał objać kontrolę nad światem. Stwierdzam to w przedostatniej części "Historii kina". Miał bardzo szeroka publiczność, która była obecna przy opracowywaniu scenariusza i formy. W ciagu niespetna dziesięciu lat, począwszy od "Okna na podwórze" aż do "Psychozy”, jego twórczość stała się tak bogata, że można go porównać do malarzy renesansowych, którzy wszak nie mieli takiej dystrybucji, może z wyjątkiem Michała Anioła w kręgach chrześcijańskich ${ }^{54}$. Twórczość Hitchcocka odegrała szczególną rolę w bardzo istotnej dla Godarda refleksji, a mianowicie w określeniu charakteru kina i jego siły oddziaływania. Jednak nie mniej ważna była dla niego sama treść i znaczenia zawarte w wyjątkowych filmach Brytyjczyka, w tym w Zawrocie głowy. Scena nieudanego samobójstwa Madeleine skaczącej z mostu Golden Gate, wyeksponowana w Historiach kina, doskonale reprezentuje skomplikowany system reinkarnacji ciała/obrazu/wspomnienia, który znajduje się w centrum uwagi Godarda od 40 lat. Alain Bergala uważa, że James Stuart ratujacy kobiete przed utonięciem jest najtrafniejsza alegoria anamnezy według Godarda: wydobyć na powierzchnię obraz - w tym przypadku zagrożonej ostatecznym zniknięciem Madeleine - i tchnać w niego życie za pomoca młodego, żywego ciała (...), to ścieżka, która prowadzi od amnezji do anamnezy ${ }^{55}$.

Inny rodzaj nawiązania Godarda do twórczości Hitchcocka wyłania się z porównania Nowej fali (filmu zrealizowanego w czasie, gdy powstawały wielogodzinne Historie kina) z Zawrotem głowy. Oba mają podobną konstrukcję, są podzielone na dwie części, a momentem krytycznym jest w nich symboliczna śmierć bohatera, który przepada w odmętach jeziora, by po jakimś czasie powrócić jako swój klon, nie będąc sobą a przynajmniej nie pamiętając o swoim wcześniejszym wcieleniu. Skok Kim Novak, rzucającej się z dzwonnicy, wyznacza - podobnie jak zniknięcie Alaina Delona w wodzie w filmie Godarda - moment śmierci $i$ zmartwychwstania $^{56}, \mathrm{co}$, jak dowodzi Bergala, jest od lat zasadniczym tematem esejów filmowych Francuza.

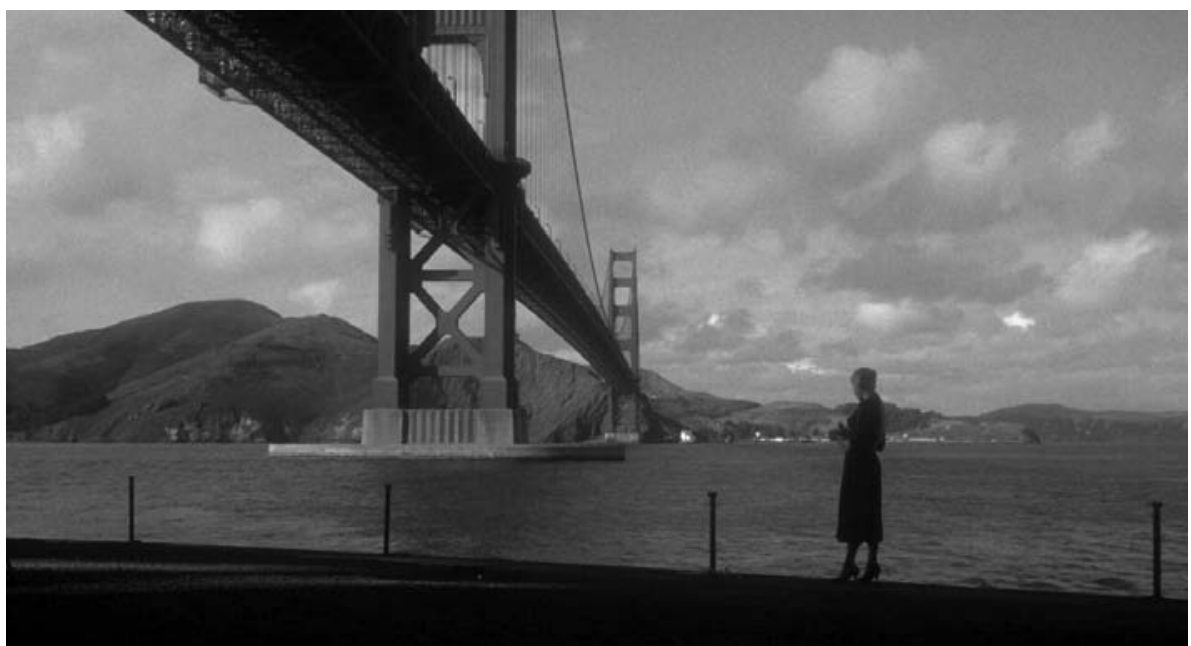

Zawrót glowy, reż. Alfred Hitchcock (1958) 
Różnicę i podobieństwo w podejściu do niektórych tematów u Godarda i Markera komentuje trafnie Bellour: Istnieja dwa sposoby traktowania nostalgii - sposób Markera i sposób Godarda. Nie chodzi o to, że Hitchcock czy Proust nawiedzaja "Immemory" $i$ "Historie kina" - dla Godarda Hitchcock jest niezrównanym mistrzem panującym nad światem, co wiaże się z władza reżyserska; dla Markera jest człowiekiem, który dotknąt pamięci w szaleństwie aż do samozatracenia [w przypadku jego bohatera]. Proust staje się dla Godarda metafora straconego czasu, który może odnaleźć jedynie kino; dla Markera pozostał tym, który otwiera się na siebie dzięki "kawałeczkowi magdalenki”, nigdy zaś dzięki "bezmiarowi wspomnieńn"57. Godarda i Markera różni „skala wielkości” w podejmowaniu tematów im bliskich - pierwszy robi to z rozmachem, szokując, roszcząc sobie prawo do przedstawienia problematyki w szerokim kontekście; dla niego wojny (zwłaszcza II wojna światowa) stanowiły cezurę historyczną i moralną na każdym polu działania człowieka: życia, sztuki, miłości. Filmy drugiego nie były pozbawione całościowego, uniwersalizującego spojrzenia, ale wynikało ono z innych przesłanek i rozwijało się w skali mikro, a także dzięki odmiennym środkom, bardziej intymnym; na tle historii ludzkiej najbardziej interesowała go historia, wspomnienie i życie jednego człowieka.

1 Por. D. Brancaleone, The Interventions of Jean-Luc Godard and Chris Marker into Contemporary Visual Art, https://www.closeupfilmcentre.com/vertigo_magazine/issue-30spring-2012-godard-is/the-interventions-ofjean-luc-godard-and-chris-marker/ (dostęp: 14.09.2021).

2 Ściślej: na jego „lewym” brzegu wraz z Alainem Resnais i Agnès Varda, którzy byli postrzegani jako bardziej wyrafinowani intelektualiści niż ci z "prawego” brzegu (skupieni wokół „Cahiers du cinéma”). Zob. V. Lowy, Rive droite, rive gauche: face à la „Nouvelle Vague”, red. K. Feigelsom, „Cinémaction" 2017, nr 165, s. 60.

3 Określenie to okazało się trafnym opisem skomplikowanych praktyk dotyczaccych niemal całej twórczości Markera. Zob. V. Lowy, dz. cyt., s. 55.

${ }^{4}$ Por. tamże, s. 61.

${ }^{5}$ Co nie znaczy, że reżyser nie nawiązywał do stylu Hitchcocka w swych wcześniejszych filmach, jednak wprost zrobił to właśnie w Historiach kina, w całości czyniąc drobne aluzje, a w części 4A wprost pokazując mistrza suspensu i konstruując historię w oparciu o jego postać.

${ }^{6}$ J. Aumont, Les théories des cinéastes, Nathan Cinéma, Paris 2002, s. 84.

${ }^{7}$ S. Jacobs, The Wrong House: The Architecture of Alfred Hitchcock, 010 Publishers, Rotterdam 2007. Cyt. za: I. Copik, Topografie suspensu w filmach Alfreda Hitchcocka, w: Krajobraz i doświadczenie, red. B. Frydryczak, M. Salwa, Przypis, Łódź 2019, s. 165.

8 Tamże, s. 74.

${ }^{9}$ Tamże.

${ }^{10}$ Tamże, s. 85.

${ }^{11}$ F. Truffaut, Le Cinéma selon Hitchcock, Editions Robert Laffont, Paris 1966. Cyt. za: J. Aumont, dz. cyt., s. 85.

${ }^{12}$ I. Copik, dz. cyt., s. 160.

${ }^{13}$ P. Ackroyd, Alfred Hitchcock, tłum. J. Łoziński, Zysk i Spółka, Poznań 2017, s. 320. Cyt. za: I. Copik, dz. cyt., s. 170.

${ }^{14}$ K. Loska, Hitchcock - autor wśród gatunków, Rabid, Kraków 2002, s. 214-216.

15 Tamże, s. 215.

${ }^{16}$ R. Bellour, L'Entre-Images. Photo, cinéma, vidéo, La Différence, Paris 1990, s. 147.

17 Tamże, s. 176.

${ }^{18}$ P. Dubois, "La Jetée" de Chris Marker ou le cinématogramme de la conscience, „Théorème” 2006, nr 6, s. 12.

19 To anegdota przytoczona przez Markera w publikacji towarzyszącej jego instalacji wideo Silent Movie na Uniwersytecie Ohio w 1995 r. Zob. V. Burgin, La marque de Marker, w: Chris Marker et l'imprimerie du regard, red. A. Habib, V. Paci, L'Harmattan, Paris 2008, s. 18-19.

${ }^{20}$ A. Pitrus, A. Helman, Podstawy wiedzy o filmie, słowo/obraz terytoria, Gdańsk 2008.

${ }^{21}$ Por. K. Loska, dz. cyt., s. 217.

${ }^{22}$ P. Dubois, dz. cyt., s. 33.

${ }^{23}$ Tamże, s. 17. 
24 Tamże, s. 38.

${ }^{25}$ J. Valkola, Sans soleil: une phénoménologie des apparences, „Cinémaction” 2017, nr 165, s. 140 .

${ }^{26}$ I. Copik, Geografie filmowe Alfreda Hitchcocka, w: Filmowe pejzaże Ameryk, red. B. Kita, M. Kempna-Pieniążek, Wydawnictwo Uniwersytetu Śląskiego, Katowice 2020, s. 67.

27 P. Mościcki, Godard. Pasaże, Korporacja Ha!art, Kraków - Warszawa 2010, s. 232.

${ }^{28}$ A. Bergala, Nul mieux que Godard, Collections Essais - Cahiers du Cinéma, Paris 1999, s. 184.

${ }^{29}$ C. Russell, Sans soleil: les infirmités du temps, w: Chris Marker et l'imprimerie du regard, dz. cyt., s. 101.

30 Tamże, s. 106.

31 Tamże, s. 110.

${ }^{32}$ R. Bellour, L'Entre-Images 2. Mots: images, P.O.L - Traffic, Paris 1999, s. 341.

${ }^{33}$ B. Laborde, Du mémorial au mémoriel: hommages et tombeaux dans l'œuvre de Chris Marker, w: Chris Marker et l'imprimerie du regard, dz. cyt., s. 146.

${ }^{34}$ L. Manovich, Język nowych mediów, tłum. P. Cypryański, Wydawnictwa Akademickie i Profesjonalne, Warszawa 2006, s. 448.

${ }^{35}$ Ch. Marker, Immemory, 1997.

${ }^{36} \mathrm{Na}$ ten temat por. I. Perniola, Atlas loci. Pérégrinations à travers la géographie markérienne, w: Chris Marker et l'imprimerie du regard, dz. cyt., s. 115-131.

${ }^{37}$ B. Laborde, dz. cyt., s. 146.

${ }^{38}$ R. Bellour, L'Entre-Images 2. Mots: images, dz. cyt., s. 358.
39 F. Niney, L'éloignement des voix répare en quelque sorte la trop grand proximité des plans, „Théorème" 2006, nr 6, s. 110.

${ }^{40}$ J.-L. Godard, Jean-Luc Godard par Jean-Luc Godard, tome 2, 1984-1998, Cahiers du Cinéma - Editions de l'Etoile, Paris 1998, s. 340.

${ }^{41}$ Komentarz reżysera w Historiach kina, cz. 4A.

${ }^{42}$ J.-L. Godard, Jean-Luc Godard par Jean-Luc Godard, Cahiers du Cinéma - Editions de l'Etoile, Paris 1985, s. 78.

43 Tamże, s. 104.

${ }^{44}$ S. July, Entretiens, „Libération” 1980, nr 2.

45 J.-L. Godard, Jean Luc Godard par Jean-Luc Godard, dz. cyt., s. 412.

46 Tamże, s. 414.

47 Tamże, s. 415.

${ }^{48}$ C. Scemama, "Histoire(s) du cinéma” de JeanLuc Godard. La force faible d'un art, L'Harmattan, Paris 2006, s. 165

${ }^{49}$ J.-L. Godard, Jean-Luc Godard par Jean-Luc Godard, dz. cyt., s. 412-415.

${ }^{50}$ Tamże, s. 415.

${ }^{51} \mathrm{~F}$. Haroudin, Le cinématographe selon Godard. Introduction aux "Histoire(s) du cinéma" ou réflexion sur les temps des arts, L'Harmattan, Paris 2007, s. 90.

52 Tamże.

${ }^{53}$ Por. C. Scemama, dz. cyt., s. 162.

${ }^{54}$ J.-L. Godard, Jean-Luc Godard par Jean-Luc Godard, tome 2, dz. cyt., s. 405.

${ }^{55}$ A. Bergala, dz. cyt., s. 224.

${ }^{56}$ Tamże, s. 236.

${ }^{57}$ R. Bellour, L'Entre-Images 2. Mots: images, dz. cyt., s. 361-362.
Barbara Kita

Kulturoznawczyni, filmoznawczyni; dr hab., prof. Uniwersytetu Śląskiego (pracuje w Instytucie Nauk o Kulturze). Zajmuje się teorią filmu i nowych mediów (zwłaszcza francuską), interesuje ją problematyka obrazu, przestrzeni oraz miasta. Autorka książki Między przestrzeniami. O kulturze nowych mediów (2003) oraz Obraz zatrzymany. Praktyka i teoria późnego Godarda (2013). Redaktorka tomu Przestrzenie tożsamości we wospótczesnym kinie europejskim (2006) i współredaktorka (z Andrzejem Gwoździem) książki Pamięć kina (2013). Wspótredaktorka (z Magdaleną Kempną-Pieniążek) książek Filmowe pejzaże Europy (2017) i Filmowe pejzaże Ameryk (2020) oraz (z Iloną Copik) Kultury obrazu - tabu edukacja (2018). Członkini Polskiego Towarzystwa Badań nad Filmem i Mediami. 


\section{Bibliografia}

Aumont, J. (2002). Les théories des cinéastes. Paris: Nathan Cinéma.

Bellour, R. (1990). L’Entre-Images. Photo, cinéma, vidéo. Paris: La Différence.

Bellour, R. (1999). L'Entre-Images 2. Mots: images. Paris: P.O.L - Traffic.

Bergala, A. (1999). Nul mieux que Godard. Paris: Collections Essais - Cahiers du cinéma.

Brancaleone, D. (2012). The Interventions of Jean-Luc Godard and Chris Marker into Contemporary Visual Art. Vertigo, (30). https://www.closeupfilmcentre.com/vertigo_magazine/issue-30-spring-2012-godard-is/the-interventions-of-jean-luc-godard-and-chris-marker/

Burgin, V. (2008). La marque de Marker. W: A. Habib, V. Paci (red.), Chris Marker et l'imprimerie du regard. (ss. 17-32) Paris: L'Harmattan.

Copik, I. (2019). Topografie suspensu w filmach Alfreda Hitchcocka. W: B. Frydryczak, M. Salwa (red.), Krajobraz i dośziadczenie. (ss. 159-176) Łódź: Przypis.

Copik, I. (2020). Geografie filmowe Alfreda Hitchcocka. W: B. Kita, M. Kempna-Pieniążek (red.), Filmowe pejzaże Ameryk. (ss. 59-77) Katowice: Wydawnictwo Uniwersytetu Śląskiego.

Dubois, P. (2006). „La Jetée” de Chris Marker ou le cinématogramme de la conscience. Théorème, (6), ss. 9-45.

Godard, J.-L. (1985). Fean-Luc Godard par Fean-Luc Godard. Paris: Cahiers du Cinéma - Editions de l'Etoile.

Godard, J.-L. (1998). Fean-Luc Godard par Fean-Luc Godard, tome 2, 1984-1998. Paris: Cahiers du Cinéma - Editions de l'Etoile.

Haroudin, F. (2007). Le cinématographe selon Godard. Introduction aux „Histoire(s) du cinéma" ou réflexion sur les temps des arts. Paris: L' Harmattan.

July, S. (1980). Entretiens. Libération, ss. 54-63.

Laborde, B. (2008). Du mémorial au mémoriel: hommages et tombeaux dans l'œuvre de Chris Marker. W: A. Habib, V. Paci (red.), Chris Marker et l'imprimerie du regard. (ss. 133-146) Paris: L'Harmattan.

Loska, K. (2002). Hitchcock - autor w'śród gatunków. Kraków: Rabid.

Lowy, V. (2017). Rive droite, rive gauche: face à la „Nouvelle Vague”. W: K. Feigelsom (red.), Cinémaction, (165), ss. 54-63.

Manovich, L. (2006). fezyk nowych mediów (tłum. P. Cypryański). Warszawa: Wydawnictwa Akademickie i Profesjonalne.

Mościcki, P. (2010). Godard. Pasaże. Kraków: Korporacja Ha!art.

Niney, F. (2006). L'éloignement des voix répare en quelque sorte la trop grand proximité des plans. Théorème, (6), ss. 101-110.

Perniola, I. (2008). Atlas loci. Pérégrinations à travers la géographie markérienne. W: A. Habib, V. Paci (red.), Chris Marker et l'imprimerie du regard. (ss. 115-131) Paris: L'Harmattan.

Pitrus, A., Helman, A. (2008). Podstawy ziedzy o filmie. Gdańsk: słowo/obraz terytoria.

Russell, C. (2008). Sans soleil: les infirmités du temps. W: A. Habib, V. Paci (red.), Chris Marker et l'imprimerie du regard. (ss. 101-113) Paris: L'Harmattan.

Scemama, C. (2006). „Histoire(s) du cinéma” de Fean-Luc Godard. La force faible d'un art. Paris: L'Harmattan. 
Valkola, J. (2017). Sans soleil: une phénoménologie des apparences. Cinémaction, (165), SS. $140-148$.

\author{
Keywords: \\ Alfred Hitchcock; \\ Chris Marker; \\ Jean-Luc Godard; \\ memory; \\ image
}

\section{Abstract \\ Barbara Kita \\ In a Sequoia Park: Hitchcock/Marker/Godard}

The text is a reflection on the relationship between the filmmakers mentioned in the title: Hitchcock, Marker, and Godard. The main idea of the article is to see the significant influence exerted by the British director on the French artists, which is manifested in the proposed approach primarily in the impact of Vertigo (1958) on Marker's La fetée (1962), Sans Soleil (1983), and Immemory (1997), as well as on Godard's Nouvelle vague (1990) and Histoire(s) du cinéma (1988-1998). It is worth noting that each of the French directors uses the same Hitchcock's film in a slightly different range. Both emphasize the universality of the story of memory/forgetfulness and appreciate the craftsmanship of the father of the thriller - an excellent stylist who was sensitive to the image. Each of them, however, created the figure of Hitchcock in their works in a different way. Marker particularly emphasized the ability to manipulate time and space, the perfection of the almost ascetic form contained in Hitchcock's simple images. Godard, in turn, relied on Hitchcock as a master of cinema, successor to great painters, who exerted great influence on the audience thanks to his ability to tell stories by means of film images. 